\title{
Erratum: Despinasse et al. Structure of the Chemical and Genetic Diversity of the True Lavender over Its Natural Range. Plants 2020, 9, 1640
}

\author{
Yolande Despinasse ${ }^{1}$, Sandrine Moja ${ }^{1} \mathbb{D}$, Catherine Soler ${ }^{1,2}$, Frédéric Jullien ${ }^{1}$, Bernard Pasquier ${ }^{3}$, \\ Jean-Marie Bessière ${ }^{4}$, Sylvie Baudino ${ }^{1}$ (D) and Florence Nicolè $1,2, *$ (D) \\ 1 Université de Lyon, UJM-Saint-Etienne, CNRS, LBVpam FRE 3727, 23 rue du Dr Paul Michelon, \\ F-42023 Saint-Etienne, France; yolande.despinasse@gmail.com (Y.D.); \\ sandrine.moja@univ-st-etienne.fr (S.M.); c_soler@orange.fr (C.S.); jullien@univ-st-etienne.fr (F.J.); \\ sylvie.baudino@univ-st-etienne.fr (S.B.) \\ 2 Laboratoire Cogitamus, $1 \frac{3}{4}$ rue Descartes, 75005 Paris, France \\ 3 Conservatoire National des Plantes Médicinales Aromatiques et Industrielles, Route de Nemours, \\ 91490 Milly La Forêt, France; bernard.pasquier@cnpmai.net \\ 4 Ecole d'Enseignement Supérieur en Chimie de Montpellier, 8 Rue de l'École Normale, 34090 Montpellier, \\ France; jeanmarie.bessiere@gmail.com \\ * Correspondence: florence.nicole@univ-st-etienne.fr; Tel.: +33-477-485-041
}

check for updates

Citation: Despinasse, Y.; Moja, S.; Soler, C.; Jullien, F.; Pasquier, B.; Bessière, J.-M.; Baudino, S.; Nicolè, F. Erratum: Despinasse et al. Structure of the Chemical and Genetic Diversity of the True Lavender over Its Natural Range. Plants 2020, 9, 1640. Plants 2021, 10, 922. https://doi.org/ 10.3390/plants10050922

Received: 7 February 2021

Accepted: 13 April 2021

Published: 4 May 2021

Publisher's Note: MDPI stays neutral with regard to jurisdictional claims in published maps and institutional affiliations.

Copyright: (c) 2021 by the authors. Licensee MDPI, Basel, Switzerland. This article is an open access article distributed under the terms and conditions of the Creative Commons Attribution (CC BY) license (https:/ / creativecommons.org/licenses/by/ $4.0 /)$.
As requested by the Editorial Office, the authors remove the scientific consortium "Camille Nous" from the author list and the Author Contributions section in the published paper [1]. To recognize the consortium's contribution, the authors had claimed a double affiliation of two of the authors to the Cogitamus laboratory [2]. The original article has been updated.

\section{References}

1. Despinasse, Y.; Moja, S.; Soler, C.; Jullien, F.; Pasquier, B.; Bessière, J.-M.; Baudino, S.; Nicolè, F. Structure of the Chemical and Genetic Diversity of the True Lavender over Its Natural Range. Plants 2020, 9, 1640. [CrossRef] [PubMed]

2. Cogitamus Laboratory. Available online: https://www.cogitamus.fr/faqen.html (accessed on 27 July 2020). 